University of Wyoming College of Law

Law Archive of Wyoming Scholarship

7-12-2007

\title{
The Plot Thickens: The Appellate Brief as Story
}

Kenneth D. Chestek

University of Wyoming College of Law, kchestek@uwyo.edu

Follow this and additional works at: https://scholarship.law.uwyo.edu/faculty_articles

\section{Recommended Citation}

Chestek, Kenneth D., "The Plot Thickens: The Appellate Brief as Story" (2007). Faculty Articles. 33. https://scholarship.law.uwyo.edu/faculty_articles/33

This Article is brought to you for free and open access by the UW College of Law Faculty Scholarship at Law Archive of Wyoming Scholarship. It has been accepted for inclusion in Faculty Articles by an authorized administrator of Law Archive of Wyoming Scholarship. 


\title{
The Plot Thickens: The ApPellate BRIEF AS STORY
}

\author{
Kenneth D. Chestek* \\ I. INTRODUCTION
}

Ellen sat at her desk for a long time after the client left.

The client's case troubled Ellen deeply. She and her son needed legal help, immediately, and it had to be decisive. Margaret Rubin, her new client, had just been devastated by the loss of her life partner, and now the legal system was attempting to take her son away from her too.

Margaret and her partner, Francie Kohler, had been a committed couple for nearly ten years. Their relationship had been sanctified by an Episcopal priest. In October 2000, they entered a civil union in Vermont after that state adopted legislation permitting the union of gay and lesbian couples.

Margaret and Francie were devoted to each other and wanted what many married couples wanted: to nurture and raise a child. But the Legislature of Old York, the state where they lived, had adopted a statute twenty years ago prohibiting homosexuals from adopting children. They therefore decided to have a child through in vitro fertilization. When Francie gave birth to their son Johnnie in 2003, Margaret moved from a full-time position to a part-time position so she could stay home and raise Johnnie.

* (C) 2008, Kenneth D. Chestek. All rights reserved. Clinical Associate Professor of Law, Indiana University School of Law-Indianapolis. This Article is based on a presentation that the Author made to the Applied Legal Storytelling Conference held in London, United Kingdom, July 18-20, 2007. The Author wishes to thank the participants in the 2007 Writer's Workshop in Boulder, Colorado, sponsored by the Legal Writing Institute. In particular, he wishes to thank Professors Steve Johansen, K.K. DuVivier, and Ursula Weigold, who provided him with outstanding feedback and wonderful ideas for how to best present the ideas expressed herein. The Author is also greatly indebted to his colleague Jim Dimitri, who co-authored the moot court problem on which the brief described in this Article was based. Special thanks go to Ruth Anne Robbins, who provided encouragement and valuable commentary throughout this project. Jennifer Drobac, Jason Eyster, Sue Liemer, Allison Martin, Jennifer Romig, and Linda Edwards also provided helpful comments on early drafts of this Article and the brief. The Author also wishes to thank the participants in the 2006 Rocky Mountain Legal Writing Conference, the 2007 Applied Storytelling Conference, and his Indiana University-Indianapolis School of Law colleagues, who provided valuable input after these ideas were presented to them. Finally, the Author wishes to thank his research assistant, Ashleigh Resetarits, 2008 J.D. candidate, for her invaluable help. 
Now Francie was gone-killed in a car-pedestrian accident while she was on her lunch break in downtown Old York. And now Francie's mother, who never approved of Francie's relationship with Margaret, was asking the state to declare Johnnie a dependant child and place him in a foster home, arguing Margaret had no legal claim to guardianship and Old York Law did not permit Margaret to adopt Johnnie. Moreover, the Old York Supreme Court had, just last year, refused to recognize the validity of civil unions entered into in Vermont.

Margaret wanted to adopt Johnnie and continue raising him. To do so in Old York, Ellen needed to overturn the Old York adoption statute, which she knew would be difficult. After all, under standard equal protection analysis, the state would only need to prove the statute was rationally related to a legitimate state interest, and she knew that most statutes survived such scrutiny.

$$
* \quad * \quad *
$$

Ellen's task in this fictional account ${ }^{1}$ is daunting. Courts tend to tread lightly when reviewing the constitutionality of legislation. Nevertheless, the mechanical application of Old York's statutory law threatened to separate a mother from her child. How can Ellen make the human drama of her case overcome the formidable legal barriers that the legal doctrine had created?

Let's be honest here. Many legal briefs, even those considered well written and logically presented, are dry. (Some might even say "boring.") ${ }^{2}$ One possible reason for this is that most legal writ-

\footnotetext{
1 The story of Margaret Rubin and Johnnie Kohler is slightly modified from a moot court problem used by Indiana University-Indianapolis School of Law in its intramural moot court competition in the fall of 2004. The "record" of that case (as modified to suit my needs for this Article), containing various fictional depositions as well as the lower court's opinion, can be found at Record of Proceedings, Rubin v. Old York County, Department of Social Services, http://papers.ssrn.com/sol3/papers.cfm?abstract_id=998322. The complete appellate brief that I wrote based upon that record can be found at Brief of Petitioner, Rubin v. Old York County, Department of Social Services, http://papers.ssrn.com/sol3/papers .cfm?abstract_id=998325. Excerpts from that brief are reproduced in this Article.

The factual scenario for this problem is based upon a storyline from season ten of the NBC television show ER, in which a lesbian physician loses her partner in a fire, and her partner's parents seek to deprive her of visitation rights to her partner's infant son. See ER Episode Guide, http://www.tv.com/er/show/111/ episode_guide.html?season=10\&tag=season _dropdown;dropdown;9; (episodes 213, 220-223) (accessed Jan. 17, 2008). The legal issue in the case is derived from a Florida statute that bars homosexuals from adopting children. Fla. Stat. Ann. $§ 63.042(3)$ (West 2005). That statute survived a constitutional challenge brought by the American Civil Liberties Union. Lofton v. Sec. of Dept. of Children \& Fam. Servs., 358 F.3d 804 (11th Cir. 2004).

${ }^{2}$ One appellate judge has characterized "[l]ong, [b]oring [b]riefs" as one of the "seven
} 
ers learn to write using the IRAC ${ }^{3}$ paradigm (or one of its related brethren, such as CRAC, ${ }^{4}$ CRuPAC, ${ }^{5}$ TREAT, ${ }^{6}$ CREXAC, ${ }^{7}$ and similar formulations). ${ }^{8}$ The paradigm is, of course, a very useful tool for constructing a legal proof, and it is welcome relief for struggling first-year students because it feels like an "answer" in a year of study that is otherwise nothing but questions.

The problem with IRAC, however, is that it doesn't have much room for people.

Think about this. "I" refers to the legal issue under consideration. No people in there. 9 The same goes for "R," the rule, which refers to the legal concepts and theories that will guide the court in reaching a decision. "A" has a bit of promise, if you take "A" to mean application, but even then, people are just objects upon which the rule operates. And if you take " $\mathrm{A}$ " to mean analysis, that is just more processing of the legal rule. The "C," or conclusion, is

sins' of appellate brief writing." Harry Pregerson, The Seven Sins of Appellate Brief Writing and Other Transgressions, 34 UCLA L. Rev. 431, 431-433 (1986); see also Philip Kissam, Law School Examinations, 42 Vand. L. Rev. 433, 477-478 (1989) (arguing the boring, "heavily criticized styles of lawyers' writing in appellate briefs" may be traceable in part to the overemphasis on what he describes as "Blue Book writing" on law school examinations); Steven Stark, Comment, Why Lawyers Can't Write, 97 Harv. L. Rev. 1389, 1390-1392 (1984) (arguing that "thinking like a lawyer" leads lawyers to write about legal precedents and doctrines, omitting the more human aspects of a controversy).

${ }^{3}$ See e.g. Charles R. Calleros, Legal Method and Writing 71-94 (5th ed., Aspen Publishers 2006); Deborah A. Schmedemann \& Christina L. Kunz, Synthesis: Legal Reading, Reasoning, and Writing 101-110 (3d ed., Aspen Publishers 2007).

${ }^{4}$ See e.g. Michael R. Fontham et al., Persuasive Written and Oral Advocacy in Trial and Appellate Courts 11-12; 46-53 (2d ed., Aspen Publishers 2007); Richard K. Neumann, Jr., Legal Reasoning and Legal Writing: Structure, Strategy and Style 101 (5th ed., Aspen Publishers 2005).

${ }^{5}$ Neumann, supra n. 4, at 101.

${ }^{6}$ Michael D. Murray \& Christy H. DeSanctis, Legal Research and Writing 95-112 (Found. Press 2006).

${ }^{7}$ Mary Beth Beazley, A Practical Guide to Appellate Advocacy 61-76 (2d ed., Aspen Publishers 2006).

${ }^{8}$ See Brian Foley \& Ruth Anne Robbins, Fiction 101: A Primer for Lawyers on How to Use Fiction Writing Techniques to Write Persuasive Facts Sections, 32 Rutgers L.J. 459, 462-463 (2001) ("Facts sections are not taught with the rigorous attention used in teaching argument sections. Most likely, this is because law schools are structured around teaching legal analysis, teaching students to look at cases, facts, and arguments coldly. Legal writing courses have followed suit."); see also Philip N. Meyer, Vignettes from a Narrative Primer, 12 Leg. Writing 229, 229 (2006) ("It may appear initially that paradigmatic forms of legal reasoning 'tame' narrative and bring narrative impulses under control, translating and reshaping the story for purposes of argumentation." (Footnote omitted)).

${ }^{9}$ It is, of course, possible to construct an issue statement based upon the factual dispute before the court; that would include the people invested in the dispute. But many appellate brief writers believe the appellate court is only interested in the law, so they only state the legal issue without setting it in the relevant factual context. 
then just the legal conclusion that flows logically from the previous pieces. ${ }^{10}$

Law, law, law. Where did all the people go in this process?

Law, and the legal system, should be about people. It decides disputes between people and provides people with neutral rules for conduct in civilized society. It is a tool to enrich and order peoples' lives. So why do legal briefs focus so much on the abstract law and overlook the people? ${ }^{11}$

The premise for this Article is that legal writing need not be-nay, should not be-boring. When we write legal briefs to a court, we are trying to resolve some human conflict. That's inherently interesting stuff. People like to hear about what other people are doing, or what has happened to them. If something bad has happened, many people want to help out in some way. It is human nature to feel empathy for somebody caught up in a conflict, and to want the conflict to be resolved.

Yet slavish adherence to the IRAC paradigm can suck the life right out of these conflicts. ${ }^{12}$ Lawyers learn in the first year of law school to break the problem into abstract little pieces, apply a set of legal principles to them, and reason out the answer in a logical way. And IRAC, being almost all about the law, is a great tool for doing just that.

I contend that a persuasive appellate brief should bring people-the client (whether human or institutional)-more conspicuously into the picture. I am not suggesting that brief writers can,

\footnotetext{
${ }^{10} \mathrm{Or}$, as Judge Kozinski colorfully put it: "There is a quaint notion out there that facts don't matter on appeal-that's where you argue about the law; facts are for sissies and trial courts. The truth is much different. The law doesn't matter a bit, except as it applies to a particular set of facts." Alex Kozinski, The Wrong Stuff, 1992 BYU L. Rev. 325, 330 (emphasis in original); but see Ruggero J. Aldisert, Winning on Appeal: Better Briefs and Oral Argument 4 (2d ed., Natl. Inst. Tr. Advoc. 2003) ("The appellate lawyer deals primarily with law, not facts ....").

${ }^{11}$ One scholar has noted that "[l]egal decisions and lawmaking frequently have nothing to do with understanding human experiences, affect, suffering-how people do live. And feeling is denied recognition and legitimacy under the guise of the 'rationality' of the Rule of Law.” Lynne N. Henderson, Legality and Empathy, 85 Mich. L. Rev. 1574, 1574-1575 (1987) (footnote omitted; emphasis in original) (citing U.S. v. Kras, 409 U.S. 434, 462-463 (1973) (Marshall, J., dissenting)).

12 Another way of saying this is that over-reliance on rule-based reasoning, and neglecting other forms of reasoning, creates a risk that the human aspects of the case will be overlooked. Professor Edwards has described what she calls different "strands" of legal reasoning, including rule-based reasoning, analogical reasoning, policy-based reasoning, consensual normative reasoning, and narrative reasoning. Linda Holdeman Edwards, The Convergence of Analogical and Dialectic Imaginations in Legal Discourse, 20 Leg. Studies Forum 1, 9-10 (1996); see also infra sec. III(A) (specifically the discussion on pages 138139).
} 
or should, disregard the law or abandon the logic of their case in favor of making a purely emotional appeal. But I am suggesting that when we write about our clients' conflicts, in an effort to resolve them, we need to keep the clients in the story. We can do this by weaving a thread of narrative reasoning into the logical, or legal, argument.

Trial lawyers have known this for a long time. ${ }^{13}$ To succeed before a jury, a trial lawyer usually needs to get the jury to empathize with their client's perspectives. Having favorable law helps, but having favorable facts is always a better bet. Trial lawyers know that they have to tell their client's story to the jury, and the story has to resonate with the jury. ${ }^{14}$

Shouldn't appellate lawyers do the same thing? If we think of appellate briefs as stories instead of pieces of technical writing, would they be more interesting and therefore more persuasive? A good novel, or a good movie, can inspire the audience. Even wellwritten non-fiction can do the same. ${ }^{15}$ If we study how these writers inspire us, perhaps we can transfer those techniques to our own writing.

Fortunately, literary scholars have studied these techniques and have developed a vocabulary for describing ones used by fiction writers to move and to inspire their readers. Legal writers can usefully employ these concepts to move and inspire their own readers: the judges and courts that must act upon the written words and render just decisions.

Many legal writers are already doing this, perhaps unconsciously and without identifying it as "storytelling." I submit

\footnotetext{
${ }^{13}$ See Ruth Anne Robbins, Harry Potter, Ruby Slippers and Merlin: Telling the Client's Story Using the Characters and Paradigm of the Archetypal Hero's Journey, 29 Seattle U. L. Rev. 767, 771 (2006) (“[A]ny decent trial lawyer already knows that storytelling is a critical part of effective advocacy.").

${ }^{14}$ See e.g. Ty Alper et al., Stories Told and Untold: Lawyering Theory Analyses of the First Rodney King Assault Trial, 12 Clin. L. Rev. 1, 4-9 (2005) (providing a number of reasons narrative technique is important in litigation and stating that juries are particularly persuaded by the technique).

15 Tom Wolfe coined the phrase "New Journalism," arguing non-fiction was "the most important literature being written in America today." Tom Wolfe, The New Journalism, preface (Harper \& Row 1973). Examples of excellent non-fiction works that read like novels abound. See e.g. Truman Capote, In Cold Blood (Random House 1965, Vintage Intl. 1994); Norman Mailer, The Armies of the Night (New Am. Lib. 1968). One recent example of persuasive non-fiction in a legal context is John Grisham's non-fiction work, The Innocent Man: Murder and Injustice in a Small Town (Doubleday 2006). The book, Grisham's first booklength work of non-fiction, reads like a crime novel. There are clear and well-drawn protagonists and antagonists, a compelling plot line, a literally life-and-death conflict, and all of the other elements of a good story.
} 
that paying closer attention to the elements of narrative can help an appellate brief writer produce a far more compelling, and thus persuasive, work. But note that "storytelling" is not limited to writing a compelling fact section of the brief. ${ }^{16}$ Rather, an essential element of a compelling story is a strong plot line in which conflict is revealed, the protagonist struggles to resolve the conflict, and the protagonist ultimately succeeds. Thus, the plot line is necessarily contained within the argument section because it is only there the conflict can reach resolution (an essential element of a satisfying story). ${ }^{17}$

I do not contend that IRAC and its brethren are inherently bad. IRAC clearly has a place in legal writing; it is a very useful tool for explaining and examining logical pieces of the legal puzzle that every case presents. But its utility is limited to small-scale organization and legal reasoning; when used to create the superstructure of a brief, it can lead to formulaic writing devoid of the personal stories that form the conflict being presented to the court. In short, IRAC is a building block-merely one type of material that a writer can use to construct a solid brief. My premise here is that what the writer builds with those blocks, the client's story, should be organized as a narrative.

\section{WHAT DO APPELLATE JUDGES SAY THEY WANT?}

The first step in crafting a persuasive argument is to analyze and understand the audience. In the case of an appellate brief writer, this task is daunting, especially when writing a brief for an intermediate appellate court that sits in randomly assigned panels. At the time she writes her brief, a lawyer almost never knows which judges will be on the panel; often she will not know the panel until shortly before, or even the day of, oral argument.

Since a lawyer usually cannot know the specific judges who will be reading her brief, she can only rely on what characteristics appellate judges commonly say they would like to see. But what do

\footnotetext{
${ }^{16}$ See Meyer, supra n. 8, at 231 ("[N]arrative persuasion in advocacy is not limited to the Statement of the Case. Narratives often shape the choice of issues and the internal organizational structure of effective arguments.").

${ }^{17}$ Foley \& Robbins, supra n. 8, at 478 (recognizing an effectively written fact section may end with the protagonist in peril, awaiting the judge's intervention to produce a satisfying conclusion); Philip N. Meyer, Retelling the Darkest Story: Mystery, Suspense, and Detectives in a Brief Written on Behalf of a Condemned Inmate, 58 Mercer L. Rev. 665, 707709 (2007).
} 
appellate judges say they want in a brief? Is narrative a good vehicle for delivering that information? After considering these questions, we will return to Ellen's story and see how she puzzles this out.

Judge Ruggero J. Aldisert, a senior judge of the United States Court of Appeals for the Third Circuit, has written extensively on judicial opinion writing as well as appellate brief writing. He has spoken with many of his colleagues on the federal and state appellate benches and has asked them what mistakes they see most often in appellate briefs. While he does not provide statistics as to which problems are perceived most often, he has listed the following items that judges generally perceive as problems: substantive errors (including things like misrepresented facts and case holdings and citing cases that have been overruled); errors in persuasion (including too many issues or points); and writing mechanics (including verbosity, lack of organization, excessive citations, typographical errors, and grammatical mistakes). ${ }^{18}$

Finally, Judge Aldisert also reports that he, and many of his colleagues, commonly observe what I would describe as a failure to tell a good story. Judge Aldisert's list includes things like: "rudderless; no central theme(s)"; "failure to disclose the equitable heart of the appeal and the legal problem involved"; "lack of focus"; and "uninteresting and irrelevant fact statements." 19 Each of these problems could be corrected if the brief writer fully identifies, and enunciates, the narrative at the heart of each case.

Recently, Brian Garner surveyed more than 100 state and federal judges. ${ }^{20} \mathrm{He}$ asked them whether they preferred a brief written as "an essay with a clear train of thought" or a brief written as "a repository of all the information that a curious judge might want to know about." 21 Of the 57 responses, he reports that 49 judges $(86 \%)$ preferred the first formulation, none preferred the second, while $8(14 \%)$ said neither model was quite right. ${ }^{22}$ If one thinks of the "clear train of thought" as the "plot line," the narra-

18 This list is condensed from a longer list of common errors found in Aldisert, supra n. 10 , at $25-27$.

${ }^{19} \mathrm{Id}$.

${ }^{20}$ Brian Garner, Judges on Briefing: A National Survey, 8 Scribes J. Leg. Writing 1 (2002).

${ }^{21} \mathrm{Id}$. at 2 .

${ }^{22} I d$. at 3. 
tive form of brief writing might be what the judges in Garner's survey are looking for. ${ }^{23}$

Ellen knew Old York was a fairly conservative state. Worse still, in the last twenty-five years, it had become a "battleground" in the culture wars. In recent elections, the Old York Chamber of Commerce had allied itself with conservative religious groups and secured the election of three conservative justices to the Old York Supreme Court, each of whom campaigned on a "family values" platform. That court now had a marked rightward tilt. Although the court had not considered any major gay rights cases in the past ten years, Ellen feared that Margaret's case could trigger an antigay backlash, not only with the public but also among the members of the court.

She needed to find a way to turn the case into something other than a gay rights case.

\section{THE TOOLS OF THE TRADE}

Fiction writing is not so different from brief writing.

An author of a fictional work certainly has more freedom because she can create facts and scenarios to suit her narrative objectives. But good fiction and good appellate briefs share several traits:

- Both are plausible.

- Both are readable.

- Most importantly, both evoke an emotional response from the reader. ${ }^{24}$

\footnotetext{
${ }^{23}$ Professor Kristen Robbins has surveyed more than 350 federal judges for their opinion of the overall quality of the legal briefs submitted to them by practicing lawyers. The survey asked judges to rate the quality of legal writing in the areas of "analysis, organization, tone, style, and mechanics." Kristen K. Robbins, The Inside Scoop: What Federal Judges Really Think about the Way Lawyers Write, 8 Leg. Writing 257, 260 (2002). She found that federal judges (both trial and appellate) believe that many lawyers generally are good at correctly identifying the legal issues, but they often fail to make the best arguments in support of their clients' positions; they also often fail to adequately refute opposing arguments. Id. at 267. Professor Robbins's survey focused almost exclusively on the logical strand of legal arguments; thus, it provides little guidance as to the persuasive power of storytelling in legal argumentation.
} 
The latter point may seem controversial at first. Appellate judges pride themselves on deciding cases on the basis of neutral principles, dispassionately understood and evenly (and logically) applied. ${ }^{25}$ We certainly do not want judges deciding cases based on emotion ... do we? ${ }^{26}$

I suggest that an appellate brief writer who overlooks the emotional appeal of her case does so at her client's great peril. ${ }^{27}$

${ }^{24}$ Any similarity of these three concepts to Aristotle's classic three types of persuasive appeals (logos, ethos, and pathos) is strictly intentional.

${ }^{25}$ Michael R. Smith, Advanced Legal Writing: Theories and Strategies in Persuasive Writing 259 (Aspen L. \& Bus. 2002) ("[R]ule-based analysis is the dominant form of reasoning. Our legal system for resolving legal disputes is based on the idea of applying established legal rules to the facts of a specific dispute."); see also Aldisert, supra n. 10, at 4.

${ }^{26}$ Professor Johansen has suggested that, in fact, we might.

While most lawyers understand that emotions can strongly influence judges and juries, many also view analytical reasoning as a more legitimate approach to legal problem solving. Because stories tend to emphasize emotions over analytical reasoning, some scholars question the appropriateness of storytelling in some legal contexts. However, when used properly, stories can enhance, rather than conflict with, analytical reasoning and are appropriate decisionmaking tools.

Steven J. Johansen, This Is Not the Whole Truth: The Ethics of Telling Stories to Clients, 38 Ariz. St. L.J. 961, 962 (2006) (footnotes omitted). Other scholars concur. Professor Henderson has noted that

a judge may react to the pain and anguish caused actual human beings by a given law or doctrine, but she will seldom point to the painful or existential consequences of that law as reason to change it. This is because the ideological structures of legal discourse and cognition blocks affective and phenomenological argument: The "normal" discourse of law disallows the language of emotion and experience. The avoidance of emotion, affect, and experiential understanding reflects an impoverished view of reason and understanding-one that focuses on cognition in its most reductionist sense. This impoverished view stems from a belief that reason and emotion are separate, that reason can and must restrain emotion, that law-as-reason can and must order, rationalize, and control.

Henderson, supra 11, at 1575-1576 (footnotes omitted; emphasis in original). Professor Neumann writes,

[a] persuasive theory is a view of the facts and the law "intertwined together" that justifies a decision in the client's favor and motivates a court to make that decision. A persuasive theory "explains not only what happened but also why" through a compelling story that "has both rational and psychological appeal" and this is "persuasive both to the mind and to the heart."

Neumann, supra n. 4, at 305 (quoting David Binder \& Paul Bergman, Fact Investigation: From Hypothesis to Proof 140, 184 (West 1984)); see also Fontham et al., supra n. 4, at 27 ("The brief should capture the human side of the case, describe the actors, and evoke sympathy for their concerns. ... Properly presented, a mixture of the human element and legal theory is intriguing.").

27 "Although lawyers are trained to value logos over pathos, juries and clients are not. Thus, a litigator who relies solely on analytical reasoning may fail to persuade non-lawyers as effectively as one who incorporates pathos into her strategies." Johansen, supra n. 26, at 980. One could argue that appellate judges, who are lawyers trained to value logos over pathos, may be more receptive to logos-based appeals than most juries and clients. However, I am not suggesting in this Article that lawyers abandon the appeal to logos; rather, I 
Certainly a purely emotional appeal is insufficient if it is not also grounded in the law and in logic. ${ }^{28}$ No matter how much a judge might sympathize with an injured plaintiff, if the law does not support recovery, recovery must be denied. But judges are people too, and a good story can have an impact on the court, especially if the rule of law (or its application) is ambiguous or unclear. ${ }^{29}$ As Linda Edwards has noted, "[l]egal reasoning is incomplete without the soil of narrative from which the reasoning grows and to which it will return." 30 She suggests that when deciding cases courts do engage in "narrative reasoning" (reasoning that "evaluates a litigant's story against cultural narratives and the moral values and themes these narratives encode"). ${ }^{31}$ Many times, judges supplement rule-based or analogical reasoning with narrative reasoning, but sometimes the only type of analysis a judge provides is the narrative reasoning. ${ }^{32}$

Robert Burns has also observed that, in a different persuasive context (the trial), lawyers can

suggest that lawyers leaven the necessary logical appeal with a healthy and well-presented dose of pathos.

${ }^{28}$ Meyer, supra n. 8, at 230 ("Narrative persuasion in the law is obviously not unbounded storytelling; narratives are constrained by and shaped to fit legal rules, legal cultural assumptions, and the conventions of legal writing practice."); see also Smith, supra n. 25. Professor Smith recognizes, however, the power of a good narrative as a way to reinforce the rule-based argument: "When a legal writer must communicate rule-based analysis, the writer, knowing the cognitive limitations of the human mind, should consider supplementing a statement of the general rule with a narrative that illustrates how the rule operated in a precedent case." Smith, supra n. 25, at 261.

${ }^{29}$ Professor Smith surveyed cognitive science literature and concluded that "humans understand concepts expressed in the form of 'stories' or 'narratives" better than they understand concepts explained as abstract principles. Id. at 259. This is because "human beings learn by interacting with and experiencing the world around them.... A person is basically the protagonist in the story that is his or her own life." Id. at 260.

${ }^{30}$ Edwards, supra n. 12, at 50. Professor Edwards also makes the point that "[r]ules are not narratives, but they are in significant part codified explications of the points of narratives, some of which are explicit and some of which form a silent sub-text of legal doctrine." Id. at 22. She concludes that "narrative reasoning and other forms of legal reasoning must function together, complementing and constraining each other .... The process of jurisgenesis arises from both dialectic and analogical processes in order that law may play its role in human living, which is likewise both dialectic and analogical." Id. at 28. Or, putting it more simply, "[r]ules restrain narratives; narratives restrain rules. Each needs the insight of the other." Id. at 9.

${ }^{31} I d$. at 11.

${ }^{32}$ Id. at 13-17. She gives the example of the case Marsh v. Chambers, 463 U.S. 783 (1983), in which the United States Supreme Court upheld the practice of the Nebraska legislature in opening its sessions with a non-denominational prayer offered by a state-paid chaplain. She shows how the Court "reasoned directly from the facts of the narrative in precisely the way one would expect it to reason from a rule." Id. at 18-19. 
construct their case from a double helix of norms. One of those strands is constituted by the law of rules. The other strand is constituted by the norms that find their natural home within the life-world of the judge and jury. These common sense norms are embedded primarily in the different sorts of narratives that the trial lawyer may employ at trial, from the fully characterized storytelling of the opening statement to the more Spartan narratives of direct examination. ${ }^{33}$

In this sense, the dual strands of rule-based reasoning and narrative-based reasoning form the DNA of persuasion.

Scholars have examined the topic of narrative in the law, especially in legal writing, from a variety of different perspectives. ${ }^{34}$ Some scholars have analyzed court decisions and applied the tools of the literary critic to consider the stories that lie at the heart of those decisions. ${ }^{35}$ Others have observed the ways in which voices on the margins of the law or the legal system have used narrative techniques to change the story and effect reform. ${ }^{36}$ I will not replow this already fertile field. However, I will explain how brief writers can put these concepts into action.

Fiction writers use a literary tool kit to construct stories that are plausible, readable, and emotionally satisfying. The kit contains at least the following elements: setting, conflict, character, point of view, theme, and plot. ${ }^{37}$

Appellate brief writers, like Ellen, can use these tools too.

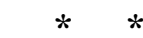

As Ellen expected, the trial court ruled against Margaret. Before the hearing, Margaret applied to adopt Johnnie, but the

${ }^{33}$ Robert P. Burns, Studying Evidence Law in the Context of Trial Practices, 50 St. Louis U. L.J. 1155, 1171 (2006); see also J. Christopher Rideout, Storytelling, Narrative Rationality, and Legal Persuasion, 14 Leg. Writing 53 (2008). Professor Neumann, in his excellent legal writing text, alludes to this concept in different terminology. He argues that a well-written brief should include both motivating arguments (i.e., arguments that make a judge want to rule a certain way) and justifying arguments (i.e., the legal rules that permit the judge to rule in that way). Neumann, supra n. 4, at 319-323.

${ }^{34}$ See generally Michael R. Smith, Rhetoric Theory and Legal Writing: An Annotated Bibliography, 3. J. ALWD 129 (2006). 2000).

35 See e.g. Anthony G. Amsterdam \& Jerome Bruner, Minding the Law (Harv. U. Press

${ }^{36}$ See e.g. Marc A. Fajer, Authority, Credibility, and Pre-Understanding: A Defense of Outsider Narratives in Legal Scholarship, 82 Geo. L.J. 1845, 1862-1864 (1994).

${ }^{37}$ See Robbins, supra n. 13, at 772 ("Within the legal framework, a story has a few key elements: character, point of view, conflict, resolution, organization, and description.”). 
county office of children and youth denied the petition because of the state law barring gays and lesbians from adopting children. The judge who heard Margaret's appeal of the county's decision was well known to the local bar as a very conservative judge. $\mathrm{He}$ frequently opined that the courts' role was limited and that judges should apply the law, not make law.

Ellen had tried three different arguments: a claim that the statute was unconstitutional under the substantive component of the Due Process Clause; a claim that the statute was unconstitutional under the Equal Protection Clause; and a claim that the court should recognize Margaret's and Francie's civil union in Vermont under the Full Faith and Credit Clause, thus rendering Johnnie legally her child. The court rejected them all. The court summarily dismissed the Full Faith and Credit Clause argument, citing a decision last year by the Old York Supreme Court that rejected the same argument in a case involving the attempted dissolution of a Vermont civil union by a couple now residing in Old York. The court rejected the substantive due process claim because the court was "not prepared to declare the existence of new rights not found in the express language of the Constitution." Ellen also ran into the same brick wall with her Equal Protection argument; the court curtly wrote that it would "not find a new suspect or quasi-suspect classification where the United States Supreme Court had not."

Most depressingly, the court hardly mentioned Johnnie or Margaret, except in the Order granting the state's motion and directing the county's child welfare office to place Johnnie in foster care pending his adoption by a heterosexual couple or individual. Fortunately, the judge stayed the effect of his opinion until Ellen could file an appeal with the Old York Court of Appeals.

Ellen knew she had to present an appealing story to the Court of Appeals.

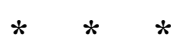

Let's examine each of the narrative tools that Ellen can use to construct her brief. ${ }^{38}$

${ }^{38}$ Note that some of the elements overlap; for example, the elements of "character" and "point of view" are closely related. For the sake of clarity, however, we will examine each separately. 


\section{A. Setting}

In fiction writing, "setting" refers to the characteristics of the time and place in which the story takes place. The author can "set" the story in a different time (the "historical" or "social" setting) or a different locale (the "physical" setting). The writer must explain both types of settings to the reader in sufficient detail so the reader can visualize the action, and understand what happens, in the correct context. The fiction writer will describe all the features of both the social and physical settings that are important to the plot, or which help the reader understand what is going on. But the writer must not include too many irrelevant details, for fear of losing the reader's attention.

In persuasive legal writing, there are also at least two different types of "settings" that the reader needs to understand: the "factual" setting and the "legal" setting. The "factual" setting is the background information about the factual dispute between the parties. We can refer to these as the "legally relevant facts" and the "helpful background detail" that aids the reader's understanding of why and how the dispute occurred. Readers want writers to exclude "distracting detail" just as much as the fiction writer wants to avoid too much distracting detail. The factual setting compares to the "physical" setting of a work of fiction.

The "legal" setting is equally important: what is the governing law that will resolve the legal issue? What is the relevant rule of law? What are the helpful "background" rules? Sometimes these rules are familiar and easily understood, and therefore do not require a great deal of explanation (the standard of review, for example); other times the rules are so murky that the writer must describe and explain those rules in detail. The legal setting is comparable to the historical or social setting in fiction.

In fiction, as in legal writing, the setting is immutable. It consists of hard, external facts that the writer cannot change. Of course, to a greater or lesser extent (depending upon the genre) the fiction writer can make up the setting, but once the author sets the story in a major metropolitan area, for example, the story is limited by the constraints of having large buildings, traffic, large crowds of people, and other attributes found in that setting. In appellate briefs, the proven facts (the record) limit the author's description of the factual setting, while the author's description of the legal setting is bound by the case law, statutes, regulations, legal doctrines, and other aspects of "the law." 
The lawyer's craft, just like the fiction writer's, lies in how the lawyer describes the setting. The setting binds the authors of both the appellant's and the appellee's briefs, yet both authors are attempting to tell stories that are fundamentally opposed to each other. As a result, each author must carefully select which details to call to the reader's attention and arrange them to evoke the response that the author wants. For example, in a novel, a vacant building might be portrayed as a safe haven, a place for the protagonist to escape from pursuers. The same building could be portrayed as a fire hazard, or a refuge for the antagonists; a place the protagonist should avoid.

Because the setting is immutable, the writer cannot ignore aspects that impede the protagonist's journey. In fiction, for example, if the author describes a river and the protagonist needs to cross the river, the author must provide a boat, a bridge, or some other means to enable the protagonist to overcome that barrier. Likewise in legal writing, a lawyer cannot ignore adverse authority; the lawyer must distinguish it, argue that it is not controlling, or provide another legal theory that supersedes the adverse authority.

The factual setting in Ellen's case was easy. Margaret's relationship with and commitment to Francie Kohler was undisputed and well-documented in the record. Likewise, her love for her son was undeniable; even the caseworker who performed the home study admitted that Johnnie was in a safe and loving environment and appeared to be quite attached to Margaret.

The legal setting, however, was more problematic. Margaret clearly had legal barriers standing in her way, chief among them the Old York adoption law. The likelihood that the court would analyze the law using a rational basis analysis was a significant legal barrier that Margaret would have to address. Ellen could encourage the court to scrutinize the statute strictly, but her chances of success with that argument were not good. She would also need to argue that the prohibition failed even lesser scrutiny.

\section{B. Conflict}

In literature, the "conflict" is the fuel that drives the story. Conflict creates interest. In literature, writers often describe con- 
flicts using broad categories, such as "person vs. person," "person vs. nature," "person vs. society," and so forth. ${ }^{39}$ Conflicts are interesting; the reader wants to understand why the conflict exists and how it can be resolved so the reader can return to a satisfying state of tranquility by the end of the story. If there are multiple conflicts, the reader wants them all resolved.

The presence of conflict in persuasive writing is, of course, obvious. There are usually two distinct types of conflicts: the factual conflict (the dispute that caused the parties to bring the case to the attention of the court), and the legal conflict (i.e., the legal issue). In persuasive writing, as in literature, conflict drives the writing. The reader wants to know how the conflict arose and how it can be, or should be, resolved.

Lawyers, like fiction writers, also describe conflicts using broad categories. The substantive law provides the lawyer with tools for converting factual conflicts into legal issues. For example, in an automobile accident, the factual conflict requires a description of the circumstances that caused the two vehicles to collide. The lawyer then labels the legal conflict as a "negligence" case and, through legal research, determines how the courts resolved similar negligence cases. In literary parlance, "negligence" would be a form of a "person vs. person" conflict. Other common person vs. person conflicts might be called "defamation," "breach of contract," etc. A genre of "person vs. society" conflict would, in legal terminology, be called "crime."

In an appellate brief the court is bound to the facts found by the trial court, and the court very rarely decides matters related to the factual conflict; instead, the appellate court resolves the legal conflict. However, the factual conflict remains relevant. Indeed, if the appellate court senses that the lower court resolved the factual conflict incorrectly, then one would expect the chances of success on appeal to be measurably greater. ${ }^{40}$

$$
* \quad * \quad *
$$

\footnotetext{
${ }^{39}$ Foley and Robbins describe the "famous list" of possible conflicts as including "man against man," "man against self," "man against nature," "man against society," "man against machine," "man against God," and "God against everybody." Foley \& Robbins, supra n. 8, at 469; see also Janet Burroway \& Elizabeth Stuckey-French, Writing Fiction: A Guide to Narrative Craft 263 (7th ed., Pearson Longman 2007).

${ }^{40}$ See discussion, supra n. 13.
} 
Ellen had several options for framing the conflict in her case. One possibility was "person vs. person" since this dispute had arisen when Stella Kohler, Francie's mother, asked the county's children's service agency to declare Johnnie a dependent child. But that conflict seemed too personal and fact-bound to attract the attention of the appellate court; framing the issue as Margaret vs. Stella seemed like Margaret was asking the court to settle a private family dispute. Ellen decided that "person v. society" would be a more compelling legal conflict. Society, through the legislature, had declared that homosexuals had fewer rights than heterosexuals. Ellen thought that she might prevail if she conveyed the personal disaster that the legislature's unilateral and sweeping choice would cause in the lives of Margaret and Johnnie.

\section{Character}

In most forms of narrative literature, character development is central to the story. Readers quickly spot the protagonists: people or institutions that the writer wants the reader to care about, to root for. Antagonists are also easy to spot. By portraying characters positively or negatively, the author creates sympathies for protagonists and against antagonists. A skillful fiction writer, of course, is not heavy-handed with character development. If the writer is too obvious, the reader will see what the writer is doing and feel manipulated; or the reader will simply not believe what she is reading because the story is too simplistic or unrealistic. Rather, the skillful writer will provide proof of each character's true nature by piling detail upon objective detail, arranged carefully to evoke the emotional response in the reader that the writer wants to create. ${ }^{41}$ Moreover, a well-developed character in a work of fiction is one that a reader can believe in: neither purely good nor purely evil, but essentially human.

Legal writers are starting to recognize the power of character development in representing clients. Ruth Anne Robbins suggests that lawyers should portray their clients in archetypal hero roles. ${ }^{42}$ She argues that "casting" a client as a hero can help the lawyer portray the client as a real and complete person; a person who needs the court's assistance. All heroes have a "quest" as well as a

\footnotetext{
${ }^{41}$ See e.g. Burroway \& French, supra n. 39, at ch. 2; Orson Scott Card, Elements of Fiction Writing: Character \& Viewpoint (Writer's Dig. Bks. 1988).

${ }^{42}$ Robbins, supra n. 13, at 775-782.
} 
"fear," and they must overcome obstacles in pursuit of the quest. By assigning the client the role of "hero," the lawyer (the "narrator") can assign the court the role of "mentor," which she describes as "a former hero who now serves as the sage advice-giver to the next hero." 43

If, as I suggested at the outset, many brief writers overlook the emotional content of the case in favor of more rational, legalistic argumentation, that is probably true because the brief writer failed to fully understand, and convey to the reader, the client's character. There may be several reasons why a brief writer might fail to fully develop the characters who inhabit the controversy. For example, in many jurisdictions, the appellate court rules that require the statement of the case to be presented in a balanced fashion, or without argument, or some other formulation of that concept. ${ }^{44}$

Failure to fully develop the characters in the brief might also be a result of inattention. We preach brevity in writing, and spend so much time on teaching legal analysis that we lose sight of the bigger picture: why did the parties act as they did? What was their motivation? Does that motivation make sense at a human, emotional level? Are their motivations emotionally appealing? Should the litigants be allowed to behave in such manners? Do they deserve punishment for their actions? Should the court want to assist one or more of the characters because what happened to them is unfair?

Finally, inattention to the element of character may be the result of the IRAC paradigm and the tendency of brief writers to focus primarily on rule-based reasoning to the exclusion of other forms of reasoning. As Steve Johansen has noted, "[m]ost lawyers are trained to persuade by logos." 45 Indeed, most legal writing texts deal explicitly with rule-based reasoning and spend a great deal of time in explaining the IRAC paradigm and its brethren. ${ }^{46}$ All of these paradigms include an $\mathrm{R}$ for "Rule," and thus (if ad-

${ }^{43} I d$. at 782

${ }^{44}$ For example, the Pennsylvania Rules of Appellate Procedure provide, "The statement of the case shall not contain any argument. It is the responsibility of appellant to present in the statement of the case a balanced presentation of the history of the proceedings and the respective contentions of the parties." Pa. R. App. P. 2117(b). Oregon requires "[a] concise summary, without argument, of all the facts of the case material to determination of the appeal." Or. R. App. P. 5.40(8).

45 Johansen, supra n. 26, at 980.

${ }^{46}$ See supra nn. 3-8. 
hered to uncritically) they seem to preclude other forms of reasoning, including the pathos-based form of narrative reasoning.

But "character" is inherently a pathos-based concept. The brief writer wants the court to identify her client as the protagonist of the story. That is to say, the writer wants the court to sympathize with her client so that the court is more likely to rule in the client's favor. Thus, if the brief writer can successfully, but subtly, identify her client as the protagonist, and the opposing party or parties as antagonists, she will have created a reason for the court to want to rule in her client's favor. This is a major step toward persuading the court to actually rule in her client's favor.

$$
* \quad * \quad *
$$

Ellen had several choices to make here. The easier choice was to choose a protagonist. She quickly decided her protagonist was the family unit comprised of Margaret and Johnnie. She chose to do this instead of portraying Margaret and Johnnie as separate, co-protagonists in an effort to avoid a possible counter-story that the state might offer: that one protagonist (Margaret) might be manipulating or exploiting the other co-protagonist (Johnnie) for selfish or immoral purposes. Emphasizing the family unit, however, held out the prospect of defusing the moral objections that the state might raise. The social conservatives who lobbied for, and won the adoption of, the anti-gay adoption measure liked to trumpet themselves as "family values" activists. How could they justify tearing apart a family in the name of preserving "family values?"

The second choice was more difficult: whom should she portray as the principal antagonist? She had several options here. She could portray the state, or the legislature that enacted the statute, as the antagonist. Or she could lower her sights and portray the local county office of children's services as the villain. She could also portray Francie's mother, Stella Kohler, as the antagonist; after all, Stella's antipathy toward Margaret had prompted Stella to seek a declaration that Johnnie was a dependent child.

Ellen decided to focus her attention on the county children's services agency. The state was too large a target, and Ellen did not like the image of the David vs. Goliath conflict that emerged. As romantically appealing as that kind of struggle might be in fiction, in the real world David lost most of the time. Likewise, making this a personal battle between Margaret and Stella made the debate sound too much like a battle of spite between two people who intensely disliked each other, neither of whom had Johnnie's in- 
terests truly at heart. But the county agency was supposed to protect children. Ellen concluded that the path to success lay in showing how the county agency's action would actually disrupt a healthy and loving family, contrary to its stated mission.

\section{Point of View/Voice}

The fiction writer has a choice of voices and points of view. She may write in the first person or the third; she may choose to be an omniscient narrator who knows all and sees all, or she may choose a more limited narrator who only sees things from the protagonist's point of view.

The brief writer, however, must write in the third person; the story is about the client and the client alone. Any attempt to use the first person will inject the lawyer into the controversy in a personal way and cause a loss of credibility. And the limited perspective of telling the story from the client's point of view is essential. A legal writer who attempts to tell the opponent's story would lack credibility; how would the writer know how the opposing party perceives things? What does she really know about what made the other party act as he, or it, did? An attempt to tell the story from the opposing side's point of view would look contrived and, therefore lack persuasive punch.

But it is still important for the legal writer to think carefully about point of view. Every contested matter contains several possible stories. ${ }^{47}$ Opposing counsel will certainly attempt to get the court to see the case from their client's point of view. If the lawyer can paint a much more credible and sympathetic picture for the court, then she will have the upper hand in persuading the court.

Ellen saw that selecting the family unit as the protagonist of her story presented some challenges. There were two members of that family unit, but one of them was legally incompetent to express himself. Still, Johnnie's point of view was perhaps the most compelling, and most persuasive, of all. He was probably unaware of the legal controversy that was brewing around him and that threatened to remove him from Margaret, the mother who had raised him from birth. He was already traumatized by the loss of

\footnotetext{
${ }^{47}$ See Edwards, supra n. 12, at 29-31; see generally Johansen, supra n. 26.
} 
his other mother, Francie. If Ellen could get the court to imagine what it might be like for Johnnie to be removed from the home where he was comfortable and loved and well cared for, and to be placed in a temporary foster home with strangers, Ellen knew that she would have a powerful story to tell.

\section{E. Theme}

Theme is another element that most brief writers consciously think about. ${ }^{48}$ In literature, we might ask what is the "moral of the story?" What lesson(s) do you want the reader to learn from your writing? At a most basic level, what is the story "about?"

An appellate brief writer will ask what "bottom line" point she is trying to prove? Why is her client's cause just, or why is the other side's cause unjust? Most texts on persuasive writing spend a great deal of time discussing how to develop a theme, or theory, of the brief. ${ }^{49}$ Judge Aldisert's text makes this point by going to the experts: skilled appellate practitioners and appellate court judges. He quotes Patricia M. Wald, Chief Judge Emeritus of the United States Court of Appeals for the District of Columbia Circuit:

Visualize the whole before you begin. What overriding message is the document going to convey? What facts are essential to the argument? How does the argument take off from the facts? How do different arguments blend together? Better still, if it's a brief, visualize the way the judge's opinion should read if it goes your way. (Too many briefs read as if the paralegal summed up all conceivably relevant facts, and then the lawyer took over with the legal arguments, and never the twain doth meet. $)^{50}$

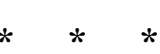

${ }^{48}$ Or at least they should think about it. One recent survey of legal writing professors, judges, and practitioners found that "lack of focus" and "failure to develop overall theme or theory of case" were the two most common errors found in legal memo writing. Susan Kosse \& David ButleRitchie, How Judges, Practitioners and Legal Writing Teachers Assess the Writing Skills of New Law Graduates: A Comparative Study, 53 J. Leg. Educ. 80, 85 (2003).

${ }^{49}$ See e.g. Beazley, supra n. 7, at 37-38; Calleros, supra n. 3, at 326-327; Fontham et al., supra n. 4, at 4-9; Neumann, supra n. 4, at 305-310.

${ }^{50}$ Aldisert, supra n. 10, at 197. 
Ellen knew she had to choose her theme carefully. If she chose too broad a theme, she risked alienating the more conservative judges who might come to hear her case. Thus, a "gay rights" theme could polarize the judges, especially on the ever-moreconservative Old York Supreme Court; it also left Johnnie's rights out of the picture. She therefore chose as her theme the concept that over-generalizations can create terrible injustice in specific cases. In particular, in this case the over-generalization that gays and lesbians are unfit parents posed a huge risk to the emotional well-being of a vulnerable three-year-old child.

\section{F. Plot}

The brief writer can use all of the preceding elements to give the reader (the court) the reasons to favor her client. But that is not the entire process of persuasion. In addition to giving the court a reason to want to rule in favor of the brief writer's client, the author also must show the court how it is legally permissible to do so. This is where the element of plot fits nicely.

The plot line is the glue that holds all of the elements together. To mix metaphors, it is the superstructure of the building: the foundation, posts, girders, and beams that carry the weight and give the building shape. ${ }^{51}$ If you want to build a solid, persuasive brief, you need to craft a strong plot line, sufficient to carry the elements of character, conflict, and theme.

Literary critics have studied plots for years. These principles also work well by analogy in persuasive legal writing. The five stages of plot development are generally described as introduction/exposition, complicating incident/rising action, climax, resolution/falling action, and denouement. ${ }^{52}$ This trajectory also describes a well-organized legal brief.

51 Jill Ramsfield has written a wonderful text on helping attorneys visualize their legal writings as works of architecture. Jill J. Ramsfield, The Law as Architecture: Building Legal Documents (West 2000).

52 Burroway \& Stuckey-French, supra n. 39, at 269. Anthony Amsterdam and Jerome Bruner describe the trajectory of a plot in different language, but covering the same basic arc:

(1) an initial steady state grounded in the legitimate ordinariness of things (2) that gets disrupted by a Trouble consisting of circumstances attributable to human agency or susceptible to change by human intervention, (3) in turn evoking efforts at redress or transformation, which succeed or fail, (4) so that the old steady state is restored or a new (transformed) steady state is created, (5) and the story concludes by drawing the then-and-there of the tale that has been told 


\section{Introduction/Exposition}

In literature, this is called "setting the stage." The setting is established: time and place are described, and relevant background details are revealed. Characters are introduced. Usually the story begins with everything in stasis; calm prevails, things are at an even keel. ${ }^{53}$

The fact section of a brief should also begin with an introduction, in which the factual setting is revealed. Helpful background details that explain the protagonist's character can be included here as well.

\section{Complicating Incident/Rising Action}

Once the stage is properly set, the action begins. Something happens. A conflict arises. The status quo is upset; something is no longer right.

Of course, the conflict drives the story and grabs the reader's attention, and the author reveals the conflict through the complicating incident in any story. The incident may be a series of incidents, one building upon another (rising action).

This is all the stuff of a compelling fact section. A good fact section (statement of the case) will reveal not only the character of both the protagonist and the antagonist, but will also define the factual conflict that brings the parties to the court, seeking redress.

But this is as far as the fact section can take you. The plot is far from fully developed yet. The reader is not ready for the climax; you cannot resolve any conflicts in the fact section. You need more.

In truth, both the "introduction" and the "rising action" must be continued in the argument section. The fact section only describes the factual setting and identifies the factual conflict. The legal setting (the fixed legal rules that must be applied by the

into the here-and-now of the telling through some coda-say, for example, Aesop's characteristic moral of the story.

Amsterdam \& Bruner, supra n. 35, at 113-114 (emphasis in original).

${ }^{53}$ Sometimes in works of fiction the "tranquility" or "stasis" condition (what Amsterdam and Bruner call the "steady state," supra n. 52) is implicit rather than express. One frequently used literary device is for the reader to be taken immediately, on the first page of the story, to the conflict, or "complicating incident" that drives the story. The reader is left to wonder what condition of stasis existed immediately before the complicating incident occurred, which can be entertaining for the reader. It does not, however, lessen the reader's desire to return to that condition of stasis by the end of the story. 
court) must be described in the argument section, and the legal conflict must be explained there as well. Thus, at the beginning of the argument section, the writer needs to complete the introduction and the "rising action" by adequately describing the legal principles that are needed to resolve the conflict. And, if there is a dispute as to what those rules are, or should be, the legal conflict needs to be developed and explained sufficiently.

\section{Climax}

In literature, the climax occurs when the protagonist is at the height of peril. Things are out of kilter, making the reader uncomfortable and aching for things to get better, to return to a condition of stasis. The reader's attention is at its peak. "How will the conflict be resolved? How does the story come out?"

In a legal brief, this moment occurs at the point in time when the reader (1) knows the characters; (2) understands the factual dispute (what happened to drive the parties to the court for assistance); and (3) understands the legal dispute (the legal principles needed to resolve the dispute). The reader wonders: "How are these issues going to be resolved? How is this going to turn out?" And in an appellate brief, the reader's interest is even more piqued because the reader is the person who ultimately gets to decide (or at least vote on) how the story "turns out."

Note that the climax must occur within the argument section of the brief because only then is the legal setting and the "rising action" of the legal issue fully developed, arriving at the climax of the story.

\section{Resolution/Falling Action}

In fiction, the climax often happens very near the end of the story because it is more entertaining that way. Once the climax is reached, the reader is usually brought back to stasis very quickly, as if riding a roller coaster. Things fall into place rapidly, and the story reaches a satisfactory conclusion, either restorative or transformative.

In legal writing, this will only happen in limited situations. If the legal rule is hard to decipher or is a question of first impression, the writer may need to spend a great deal of time with the "rising action" to arrive at a sufficient description of the legal issue, explained clearly enough that the court can then take appro- 
priate action. In such situations, once the difficult rule is synthesized, the application of that rule to the facts may be fairly straightforward, resulting in a very short section of falling action/resolution.

The more common situation, however, will be the opposite: the rules are fairly straightforward, but the way in which they should be applied to the peculiar facts of the case at hand may be more difficult. In that situation, the falling action/resolution part of the plot is likely to be much more complex and lengthy.

\section{Denouement}

And then there is the conclusion.

Readers of fiction generally like happy endings. All of the conflicts are resolved in a plausible way and the characters return to a state of peace and calm. The resolution can be a return to the prior condition of stasis (a restorative resolution), or to a new, yet tranquil and satisfying, condition (a transformative resolution). ${ }^{54}$

Likewise, the legal brief must come to a plausible conclusion. The writer returns to the theme that has been developed throughout the plot and makes it explicit. All of the conflicts are resolved, and the court is led to a calm, rational, and just conclusion: your client wins, either by being restored to status quo ante or by being placed in a new, satisfying condition, consistent with the theme of the narrative.

So now it is time for Ellen to start writing her brief.

\section{APPELLANT'S BRIEF IN THE CASE OF RUBIN $v$. OLD YORK COUNTY DEPARTMENT OF SOCIAL SERVICES}

\section{A. The Fact Section}

Ellen knew that the appellate court was likely to be even less sympathetic to Margaret's and Johnnie's plight than was the trial judge. The appellate court, after all, would not have to look into Margaret's or Johnnie's eyes and explain to them why the mother and child bond they had formed over the past three years would have to be broken to satisfy the preferences of a legislative body from twenty years ago that knew, and cared, nothing about them.

\footnotetext{
${ }^{54}$ Amsterdam \& Bruner, supra n. 35, at 114.
} 
To succeed, Ellen knew she would have to make Margaret and Johnnie real to the appellate court. At the same time, she understood that she had to avoid manipulation. The story had to ring true-to make sense to the appellate judges at a gut level. The emotions she wanted to evoke from the judges had to come from within them, so the emotions would be real.

She wrote the fact section:

Margaret Rubin and Francie Kohler only wanted a child.

Having committed themselves to each other emotionally and legally, they decided, as do many committed couples, that they wanted to raise a family. But the state of Old York told them that they were unfit parents, simply because they loved each other. Without knowing anything about the depth and sincerity of Margaret's and Francie's commitment to each other, and without any individualized investigation into their fitness as parents, the state categorically declared that they, along with all other gay and lesbian citizens, were unfit to adopt and raise children.

Margaret and Francie were devoted to their dream, however. They had overcome obstacles before. In 1995, when Old York would not recognize their relationship, Margaret and Francie went to Father Roger Smith, an Episcopal priest, who sanctified their marriage. In 2000, soon after the Vermont legislature approved a measure allowing gays and lesbians to enter into civil unions, Margaret and Francie went to Vermont and entered such a union.

In 2002, Margaret and Francie went to several adoption agencies, seeking to be approved as adoptive parents. No agency would accept their application, however, since an Old York statute approved in 1986 provided that homosexuals could not adopt children. Undaunted, the couple then sought the services of the Old York Fertility Clinic. Through a process of in vitro fertilization, Francie became pregnant, and in August of 2003, Francie gave birth to a son, John Rubin Kohler.

Since Francie's job as vice president of Beautimous Cosmetics was both time-consuming and financially lucrative, the couple decided that Francie would return to work, while Margaret would stay home to raise Johnnie. The arrangement worked well, and the couple could not have been happier.

On September 9, 2006, Francie left her office in downtown Old York to get some lunch. A cab driver ran a red light at a high rate of speed and struck Francie, killing her instantly.

Francie left no will. Since Old York does not recognize the Vermont civil union, Francie's mother Stella Kohler sought and 
was awarded letters of administration for Francie's estate. Stella, who never approved of Margaret's relationship with Francie, also petitioned the Old York County Office of Children and Youth (OCY) to have Johnnie declared a dependent child, despite the fact that Johnnie had resided with Margaret since birth and calls Margaret "Mommy." Because Stella is in ill health and unable to care for a young child, she asked OCY to place Johnnie in a foster home and ultimately for adoption.

Margaret immediately filed a petition to adopt Johnnie, notwithstanding the Old York statute prohibiting homosexuals from adopting. OCY assigned one of its caseworkers, Delia Clarke, to do a home study. Ms. Clarke testified at her deposition that she found Margaret to be "a devoted mother" who was "very attentive" to Johnnie, "treating him in an age appropriate manner." She said that Johnnie "seemed to be quite happy" and that he was "quite attached to his mother." She also concluded that the home was clean and safe, but despite these findings, Ms. Clarke recommended that the adoption petition be denied, solely because Margaret admitted that she was a lesbian.

On March 3, 2007, the Superior Court of Old York County approved Ms. Clarke's recommendation, and denied Margaret's petition for adoption. It also ordered Johnnie to be taken from Margaret by OCY and placed with a foster family, pending adoption proceedings "by a heterosexual couple or individual." The court did, however, stay enforcement of its order pending this appeal.

[Citations to record omitted.]

$$
* \quad * \quad *
$$

Ellen's fact section begins with some character development. Margaret and Francie are introduced as loving people with natural human instincts: they want a family. The factual setting of the case is then developed. The couple faces an initial hurdle: the state, portrayed as antagonist, prohibits them from adopting because it disapproves of their relationship. But they persevere, and the protagonists win the initial battle: the state cannot prevent either of them from conceiving a child through medical technology. The introduction is now complete. Thus, the story begins from a condition of stasis: a loving family with a healthy child.

Then the complicating incident arrives, beginning the "rising action" of the plot line: Francie is killed in an automobile accident. The heroine's tragic flaw is revealed: she and Francie had neglected to anticipate and plan for this possibility. Francie left no will, and therefore Margaret cannot be appointed the legal guard- 
ian for her young son. A new antagonist appears on the scene: Francie's mother, who disapproved of Margaret's relationship with her deceased daughter and now wants to prevent Margaret from raising her grandchild. She joins forces with the original antagonist, the state, and moves swiftly to try to take Johnnie away from Margaret. A third antagonist, the Old York Office of Children and Youth, also appears. In the event of a victory by the state in this case, that agency would have to carry out the dirty deed of entering Margaret's home and physically removing Johnnie to a foster home. OCY is set up to become the principal antagonist. OCY is portrayed as uncaring. Despite the fact that its agent, Delia Clarke, finds the home safe and Johnnie well cared-for, the agency denies the petition for adoption. Ellen's theme (that overgeneralizations can do great violence to individuals in specific cases) begins to emerge.

The fact section thus describes the characters who inhabit the story, and introduces the factual conflict. The factual setting is thus complete. The final paragraph (describing the procedural history of the case, a section almost universally required by appellate court rules) also serves as a transition to the argument section, where the rising action will continue with a discussion of the legal setting (the rules of law that will govern the resolution of the conflict).

\section{B. The Argument Section}

The facts, Ellen knew, were her best asset in this case. But Ellen knew that strong facts clearly were not enough, especially on appeal where the rule of law and logic predominated. Ellen needed to create a plausible, if not compelling, legal rationale to allow the court to do what she felt the facts of the case required: preserve the family that Margaret and Johnnie had formed.

Ellen knew that the case law was problematic. Sexual orientation had never been defined as a "suspect classification" for Equal Protection analysis. While the Lawrence $v$. Texas case had been helpful, it still had stopped short of declaring private sexual intimacy a "fundamental right" under the Due Process Clause..55 Moreover, while the Supreme Court had given lip service to the concept that "family integrity" was a fundamental right, no major-

55539 U.S. 558 (2003). 
ity opinion had ever applied that principle in a case where there was no blood relationship between the members of the putative family. Thus, it appeared likely that the Old York Court of Appeals would likely apply a rational basis test to Ellen's constitutional challenge, and that was an uphill battle. Ellen saw little hope that the Old York appellate courts would reverse direction on the Full Faith and Credit Clause issue so soon after resolving the question against her client's position.

Ellen elected to forego the Full Faith and Credit Clause argument in favor of what she considered her stronger arguments based on the Fourteenth Amendment. Ellen decided that, while she needed to raise the issue of the appropriate level of scrutiny (in order to preserve that issue for subsequent appeals, if necessary), at the intermediate appellate level her client's best hope for success lay in showing the irrationality of disrupting a stable and loving home and placing Johnnie in limbo, with strangers, in the foster care system.

Ellen began:

Margaret Rubin is challenging the constitutionality of the provision in the Old York adoption law that denies gay and lesbian adults the right to adopt children. The trial court denied her appeal as a matter of law. This Court reviews such decisions de novo. Jones v. Exposition Services, Inc., 835 O.Y.2d 425 (2000).

The Old York adoption statute provides:

\section{§ 19-67-2 Persons eligible to adopt}

(A) The following persons are eligible to adopt:

(1) A husband and wife together; or

(2) An adult who is not married.

(B) Homosexuals are not eligible to adopt under this statute.

O.Y. Civ. Code Ann. § 19-67-2 (East Pub. Co. 2003) (hereinafter "the Prohibition"). The Old York legislature added Subsection (B) by amendment in 1986, after a highly publicized incident in which a prominent musician was convicted of sexually abusing his adopted son. State v. Smith, 489 O.Y. 142 (1985); Musician's Conviction Prompts Legislative Reaction, Old York Times, Jan. 6, 1986, p. 1, col. 3.

The Prohibition violates the Fourteenth Amendment to the United States Constitution in two ways. First, the Prohibition 
deprives Rubin of her fundamental right to privacy, and it deprives Rubin and her son Johnnie of their right to family integrity, both in violation of the substantive component of the Due Process Clause. U.S. Const., Amend. XIV, cl. 3. Second, the Prohibition discriminates against gay and lesbian individuals, a classification that this Court should find to be a suspect or a quasi-suspect classification, in violation of the Equal Protection Clause. U.S. Const., Amend. XIV, cl. 4. Accordingly, this Court should strictly scrutinize the Prohibition and declare it unconstitutional because it is not narrowly tailored to serve a compelling state interest.

Even if the Court declines to apply strict scrutiny, the Prohibition fails because it is not rationally related to any legitimate state interest. The Prohibition was enacted in reaction to a single incident involving a gay parent; it was therefore enacted out of animus toward homosexuals in general. Such animus can never be a legitimate state interest. Moreover, the Prohibition results in an irrational destruction of a healthy family unit in this case. The evidence establishes that Rubin has provided a safe and loving environment for her son and that Johnnie is happy and emotionally attached to his mother. Destruction of this family unit because of an irrational reaction by the legislature more than twenty years ago can only wreak unknowable emotional damage on Johnnie and potentially expose him to years of instability and uncertainty in the foster care system. No legitimate state interest would be served by such a result.

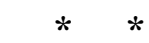

The plot thickens. Having revealed the factual setting and the factual conflict in the statement of the facts, Ellen now proceeds to establish the legal setting (the foundational law necessary to resolve the dispute) and the legal conflict (the issue presented to the court for decision). This is still the introduction/exposition portion of the plot, although this passage ends with the hint of conflict. The first few paragraphs establish the legal landscape: the standard of review and the statute adopted by the Old York legislature. Some background information as to why the statute was adopted is provided; these details will later help support a claim of "animus" in the adoption of the statute, serving to de-legitimize the state interest served by the statute.

The "road map" paragraphs at the end of this passage conclude the exposition. They describe where the legal issues will be encountered in the remainder of the brief. They serve both as "fo- 
reshadowing" of the conflicts to arise in the coming pages and as a neat transition to the "rising action" portion of the plot.

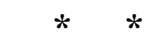

Ellen continued.

\section{A. The Court Should Strictly Scrutinize the PROHIBITION.}

Because the Prohibition impinges on fundamental rights of both Rubin and Johnnie, and because it discriminates against Rubin on the basis of her sexual orientation, this Court should strictly scrutinize it.

\section{Margaret Rubin Has a Fundamental Right UNDER THE DUe Process Clause.}

The Supreme Court has long held that the Due Process Clause includes a substantive component that "protects individual liberty against 'certain government actions regardless of the fairness of the procedures used to implement them." Washington v. Glucksberg, 521 U.S. 702, 719 (1997) (quoting Collins v. City of Harker Heights, 503 U.S. 115, 125 (1992)). More specifically, the Due Process Clause "provides heightened protection against government interference with certain fundamental rights and liberty interests." Glucksberg, 521 U.S. at 720.

The Court looks to history to determine whether an asserted right is a "fundamental right" protected by the substantive component of the Due Process Clause. The Court asks whether the asserted right is "deeply rooted in this Nation's history and tradition" and "implicit in the concept of ordered liberty," such that "neither liberty nor justice would exist if [it was] sacrificed." Id. at 720-721. If the answer to this question is "yes," then the asserted right is a fundamental right entitled to heightened protection under the Due Process Clause.

The Court has identified numerous "fundamental rights" in the past: the right to marital privacy, Griswold v. Connecticut, 381 U.S. 479 (1965); the right to marry, Loving v. Virginia, 388 U.S. 1 (1967); the right to have children, Skinner v. Oklahoma, 316 U.S. 535 (1942); the right to direct the education and upbringing of one's children, Pierce $v$. Society of Sisters, 268 U.S. 510 (1925); Meyer v. Nebraska, 262 U.S. 390 (1923); the right to use contraception, Eisenstadt v. Baird, 405 U.S. 438 (1972); Griswold, 381 U.S. at 485-486; the right to bodily integrity, Rochin v. California, 342 U.S. 165 (1952); and the right to abortion, Planned Parenthood v. Casey, 505 U.S. 833 (1992). The Court has also assumed and suggested, but not specifically de- 
cided, that there is a fundamental right to refuse unwanted, lifesaving medical treatment. Cruzan v. Director, Mo. Dept. of Health, 497 U.S. 261 (1990). Finally, the Court has held that the "private realm of family life" includes the "fundamental right of parents to make decisions concerning the care, custody, and control of their children." Troxel v. Granville, 530 U.S. 57 (2000).

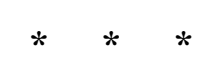

The "rising action" has begun. The brief now begins to explore, and develop, the legal conflicts identified in the final paragraphs of the exposition. Several sub-plots are identified: the potential conflict between the adoption statute and the Due Process Clause, as well as its potential conflict with the Equal Protection Clause. More legal setting is revealed in the form of additional case law that may help, or harm, the protagonists in their quest.

In the interest of brevity, the entirety of Ellen's brief will not be set out herein. Her point headings, however, describe how she manages the rising action portion of the argument:

\section{A. The Court Should Strictly Scrutinize the Prohibi- tion.}
1. Margaret Rubin Has a Fundamental Right under the Due Process Clause.
a. Margaret Rubin has a fundamental right to privacy.
b. Margaret Rubin and Johnnie Kohler have a fundamental right to family integrity.
2. Sexual Orientation Should Be Recognized as a Suspect Classification.

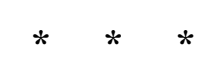

Under each of these point headings, Ellen expanded upon the concepts introduced in the exposition. She engaged in a thorough explanation of why the Supreme Court had chosen to apply strict scrutiny in the contexts of both "fundamental rights" analysis under the Due Process Clause and for discrimination claims under 
the Equal Protection Clause. Ellen concluded each section with an argument that the court should apply strict scrutiny to the statute, but she stopped short of showing how the statute would measure up under such scrutiny. Instead, each sub-section ended with a reminder that enforcement of the statute would destroy the family unit. For example, she concluded section A(1)(b) with these paragraphs:

In the case at bar, Rubin and Johnnie have developed an extremely close "custodial, personal [and] financial relationship." Rubin has raised Johnnie as her son since birth, and with the sudden traumatic death of Francine Kohler, Rubin is the only remaining source of stability in Johnnie's life. And unlike the situation presented in Smith, there is no competing claim in this case from a blood relative; Francine's mother, Stella Kohler, has told OCY that she is unwilling to serve as Johnnie's custodian. The choices for Johnnie are to stay with the loving mother he's known his whole life or to be put in the foster care system.

Nothing could be more fundamental than a bond formed between a mother and the three-year-old child whom she has raised since birth. Strict scrutiny of the Prohibition is, therefore, required to prevent the OCY from tearing this family apart.

[Citations to record omitted.]

$$
* \quad * \quad *
$$

By the end of Ellen's second sub-point heading (dealing with the Equal Protection argument for strict scrutiny), the rising action of the plot was complete. Margaret's and Johnnie's peril was fully exposed: the OCY was poised to snatch Johnnie out of Margaret's arms, on the authority of a twenty-year-old statute adopted in the heat of a long-forgotten passion. Several avenues of escape from this peril had been identified: perhaps the statute violated the Due Process Clause, or the Equal Protection Clause, of the United States Constitution. Will the protagonists be able to successfully escape to safety through either of those avenues? The reader, who wants resolution now, is interested to see how this story turns out.

We have reached the climax of the story. Now it is time to start resolving the conflicts. 
Ellen devoted her second major point heading to showing how, under either strict or intermediate scrutiny or under rational basis analysis, the court should strike down the adoption statute. She structured this portion of her brief like this:

B. The Prohibition Fails under Either Strict Scrutiny, Intermediate Scrutiny, or Rational Basis Analysis.

1. The Prohibition Fails under Strict and Intermediate Scrutiny.

a. The Prohibition does not serve any compelling or important state interest.

b. The Prohibition is not narrowly tailored.

2. The Prohibition Fails under Rational Basis Analysis.

a. The Prohibition was enacted out of animus toward gay and lesbians, which is not a legitimate state interest.

b. The Prohibition is irrational.

$$
* \quad * \quad *
$$

This organizational structure reveals one of the important distinctions between fiction writing and brief writing. Unlike the readers of fiction, readers of legal briefs do not read for entertainment. They read for information. Thus, entertaining devices, like "suspense," don't usually work.

In a novel, the hero might try the safest route of escape from his peril first; if that route is blocked, or his escape is unsuccessful, he might try a riskier route. It is more entertaining to the reader if the riskier route is hidden from the reader's view until the last moment. A judge reading a brief, however, wants information-not entertainment. Thus, Ellen chose to reveal both possible escape routes: the "safe" (from her client's point of view) route of strict or intermediate scrutiny and the riskier path of rational basis analysis.

Ellen's brief then plays out each of these possible escape routes. She argues that there is no compelling, or even legitimate, state interest in denying gays and lesbians the right to raise children; thus, under either strict or intermediate scrutiny, the statute 
fails. She concludes, as she must, with her "fail-safe" argument: that even under rational basis analysis, the statute fails because (a) the statute was apparently adopted out of animus toward homosexuals, which can never be a "legitimate state interest," and (b) the statute is not rationally related to any legitimate interest because it does not take into account the familiar, and well-settled, "best interest of the child" standard.

$$
* \quad * \quad *
$$

Ellen had learned in law school that she should "lead with her strongest argument." 56 She thought her strongest argument was that the Old York statute had no mechanism for taking into account its impact on the children. In making custody decisions, the courts routinely recited the "best interest of the child" standard; yet the statute gave no weight at all to that bedrock principle. However, when she put that argument up front, the brief did not seem to flow well. She decided to save that argument for last and end her brief with a bang:

Even if, like the trial court, this Court frames the issue here as an effort to "encourage a stable and nurturing environment for the education and socialization of its adopted children," Lofton, 358 F.3d at 819, the Prohibition is not rationally related to that end. There is no evidence in this record, or in the social science literature, that suggests that gays and lesbians are categorically incapable of providing a stable and nurturing environment in which to raise children. Yet this enactment of the Old York legislature prohibits all gay and lesbian individuals from adopting children without even a minimal inquiry into the circumstances of the proposed adoption. No consideration is given to the best interest of the child, which has been described by Old York Supreme Court as "the touchstone consideration in every child custody case," including adoption cases. In re Adoption of $O, 719$ O.Y.2d 873 (1997).

Nor would removing Johnnie from Rubin's home rationally serve the state's claimed interest in stable homes for adopted

56 This "conventional wisdom" has been validated empirically. In a recent survey of 355 federal court judges (both trial and appellate courts), $74 \%$ of the respondents said it was "essential or very important for advocates to put their strongest arguments first." Robbins, supra n. 23, at 273. However, this general rule of thumb can always yield to other organizing principles, such as the logical structure of the argument based upon the legal issues. Here, it seems that Ellen's choice to put her rational basis argument last is the logical way to organize the legal analysis. 
children. In fact, as Delia Clarke found, Johnnie is already in a stable and nurturing environment in Rubin's home. Removing him from the mother he has known and loved from birth, and who has been found through the home study process to be a loving and nurturing mother, to be placed in foster care awaiting adoption at some unknown future time by strangers, can only serve to traumatize this young boy.

The emotional damage such an outcome would produce is impossible to predict, but is certain to be significant. Old York County's own statistics show that the median time a child older than a toddler spends in the foster care system is four years. Thus, if Johnnie turns out to be the average case, he would be seven years old before he were placed in another stable, longterm home-once again with people he did not know. What purpose is served by this, when he is already in a stable, loving, and nurturing home?

For all of these reasons, the Prohibition, amended into the Old York adoption statute in 1986, is not rationally related to any legitimate state interest. It must therefore be declared unconstitutional.

[Citations to record omitted.]

$$
* \quad * \quad *
$$

The resolution/falling action portion of the plot is now complete. The peril of the protagonists, made explicit at the moment of climax, can be resolved. A transformed "steady state" (the removal of the legislative impediment to the continuation of this family) is not only possible, but is emotionally satisfying because it preserves Johnnie's normal and healthy relationship with his mother.

All that remains is the denouement.

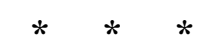

Ellen wrote the conclusion:

The 1986 amendment to the Old York adoption law violates the privacy of every prospective adoptive parent by requiring them to answer intensely personal questions regarding their sexual orientation. It violates the fundamental right to family integrity by forcefully separating a mother from the child she has raised from birth, for no reason other than animus expressed by the legislature against homosexuality. The best interest of the child, which should be the primary consideration, is not taken into consideration at all. 
Whether strict or intermediate scrutiny or rational basis analysis is applied, the Prohibition violates the Fourteenth Amendment to the United States Constitution. This Court should declare the 1986 amendment unconstitutional, and remand this case with instructions to the lower court to approve the adoption of Johnnie Kohler by Margaret Rubin.

\section{NARRATIVE THEORY IN APPELLATE BRIEFS}

How does conceiving of an appellate brief as a story change the brief?

I submit there are at least two salutary effects of consciously thinking of the brief as a narrative. First, narrative theory provides the writer with a useful large-scale organizational schema. Second, narrative forces the writer to focus on the human elements of the controversy, and thus serves as a reminder to include a strong narrative strand of argumentation.

\section{A. Narrative as a Tool for Large-Scale Organization}

Philip Meyer has suggested that excessive reliance on structural paradigms (all of which are rule-based) may have a tendency to "tame narrative." ${ }_{57}$ This is true if the author attempts to use IRAC as a large-scale organization device. But IRAC really does not work well for such purposes. While it is a useful device for structuring parts of a legal proof, its utility is limited to the logical strand of the argument. This is because IRAC is a specialized form of a syllogism, ${ }^{58}$ the principal mode of logical reasoning. Given that most cases involve multiple issues and sub-issues, a legal brief requires multiple syllogisms (IRAC structures). The author is left to her own intuition as to how to organize these logical pieces into a coherent whole. Much of the scholarship and commentary on large-scale organization focuses on the legal, rather than the narrative, strand of the argument, compounding the tendency of appellate brief writers to focus on the logos at the expense of the pathos. ${ }^{59}$

\footnotetext{
${ }^{57}$ Meyer, supra n. 8.

58 "The syllogism is the vessel which contains IRAC, not the other way around." James Boland, Legal Writing Programs and Professionalism: Legal Writing Professors Can Join the Academic Club, 18 St. Thomas L. Rev. 711, 721-722 (2006).

${ }^{59}$ See e.g. Beazley, supra n. 7, at 49-58 (describing how to use the logical structure of
} 
Narrative, however, is organized through the plot line: stasis, rising action, climax, falling action, and denouement. Its very purpose is to provide large-scale organization. I suggest the story line is a good way to think about the large-scale organization of a brief.

Consider the brief that Ellen might have written if she tried to use pure logic as the large-scale organization scheme. It might have looked something like this:

\section{ARGUMENT}

INTRODUCTION (foundational law regarding standard of review, roadmap)

\section{A. Substantive Due Process Claim}

1. Issue: level of scrutiny

2. Rule

a. Strict scrutiny if fundamental right

i. Right to privacy, or

ii. Family integrity

b. If neither, rational basis

\section{Application}
a. Strict scrutiny
b. Rational basis

\section{Conclusion: Rubin wins}

\section{B. Equal Protection Claim}

\section{Issue: level of scrutiny \\ 2. Rule}

\section{a. Strict scrutiny if suspect classification}

\footnotetext{
the statutory or case law to outline the discussion section of an appellate brief); Calleros, supra n. 3, at 330 (suggesting that an advocate should consider departing "from a purely logical ordering of the arguments" to present one's strongest argument first); Fontham et al., supra n. 4, at 13-15 (suggesting that advocates lead with their best argument unless the requirements of the law dictate another structure); but see Linda Edwards, Legal Writing: Process, Analysis and Organization 307-309 (4th ed., Aspen Publishers 2006) (describing four "common choices" for large-scale organization of a brief: organizing by strength of law, organizing by strength of equities, ordering by the reader's priorities, and ordering by familiarity. Of those four options, the second describes an organization scheme based upon the emotional appeal of the arguments, while the others describe logos-based considerations).
} 
i. Sexual orientation has not yet been identified as suspect classification

\section{ii. But it should be}

b. Intermediate scrutiny if quasi-suspect classification

i. This is similar to gender discrimination

\section{ii. The court should recognize a new category of intermediate scrutiny}

c. If neither of the above, rational basis test

\section{Application}

\section{a. Strict scrutiny}

b. Intermediate scrutiny

c. Rational basis analysis

\section{CONCLUSION: Rubin wins}

A brief structured in this manner might be pleasing to some readers; certainly a competent brief could flow from this structure or some variant of it. ${ }^{60}$ But does it flow as well as the "narrative brief" that Ellen wrote? For one thing, the structure feels very rigid and mechanical; all logos and no pathos. For another thing, this brief will likely be longer, because the application of the rational basis test is the same under either the Due Process or Equal Protection questions, requiring some duplication of analysis. It might also be disjointed because, to save words, the author might cross-reference the rational basis application from one issue to the other. Either solution would be unsettling to the reader.

Now consider the structure of the brief that Ellen actually wrote, using the storyline as her organizational principle:

${ }^{60}$ A more sophisticated brief following the IRAC paradigm, for example, might have broken down each of the two main issues (due process and equal protection) into two subissues: strict scrutiny and rational basis review. Each sub-issue would then get its own IRAC sequence. Such a structure would still be unsettling to some readers, because it requires the reader to endure four separate analyses. Moreover, since some of the analyses are closely related to each other (the rational basis analysis, for example, is virtually identical in both the due process and the equal protection arguments), the reader might get impatient because it feels like the author is repeating herself. 


\section{ARGUMENT}

EXPOSITION (foundational law regarding standard of review, road map; legal conflict revealed)

\section{A. Rising action}

1. First sub-plot (Due Process claim)-legal setting explained

a. Right to privacy

b. Family integrity

2. Second sub-plot (Equal Protection claim)legal setting explained

a. Suspect classification

b. Quasi-suspect classification

$\{$ CLIMAX (the factual and legal settings are complete, the conflict is apparent, the protagonists are at maximum peril)\}

\section{B. Falling action}

1. "Safe" escape from peril tested (strict/ intermediate scrutiny)

2. "Risky" escape from peril tested (rational basis review)

\section{CONCLUSION (Denouement)}

One might argue that Ellen's "narrative brief" is not all that different from the logic-oriented brief (let's call it the "IRAC brief") described above. Or, stated another way, could reliance on IRAC as a large-scale organization structure lead one to write the narrative brief? Isn't it just a question of how one defines the "issues?" Specifically, one might argue that while the IRAC brief defines the two main issues as Due Process analysis and Equal Protection, the narrative brief just defines two different issues: "(1) What is the appropriate standard of review?" and "(2) Does the Old York statute serve appropriate state interests?"

Upon close examination, however, the narrative brief is actually different in kind rather than just different in form. The IRAC brief is structured entirely on the "rule-based" strand of the legal analysis. It defines two rule-based issues (based upon two separate clauses of the Fourteenth Amendment), breaks those rules down into their logical sub-parts (i.e., what is the appropriate level of scrutiny under each rule, based on prior case law), and ultimately 
applies the formulaic rules resulting from the possible outcomes of the scrutiny inquiry: does the statute serve a "compelling state interest" (as defined by case law)? Is it rationally related to a "legitimate state interest" (again as defined by case law)? The focus of this analysis is heavily dependent upon rules, and very little attention would likely be paid to the narrative "strand" of the analysis.

Most importantly, nothing about the logical structure of the IRAC brief seems to require the writer to bring in the narrative strand. The question of determining the proper level of scrutiny (the " $R$ " portion of the IRAC brief) is a pure question of law, dependent upon case precedent and standard rule-based analysis. Once that question is resolved, the application of the appropriate level of scrutiny is also rule-based. The challenged legislation is measured against whatever level of scrutiny the author needs to analyze; the rules relevant to how one performs the measurement are set forth in precedent cases and applied mechanically.

Certainly, a clever advocate could, and should, find a way to personalize the application of the law to the Old York statute and to raise the reader's sights above the pure legal question involved. But the point is that doing so requires bending or breaking entirely out of the IRAC paradigm. This suggests that the utility of the IRAC paradigm is limited, which in turn leads to my second point.

\section{B. Narrative as "Reality Check"}

On the other hand, organizing a brief using the narrative paradigm provides the tools for the author to bring in the human aspects of the controversy. By recognizing that rule-based reasoning and narrative-based reasoning are two distinct strands, wound together in the double helix that Burns describes, ${ }^{61}$ the author of the brief is constantly reminded of the client's story and the need to tie it into the legal analysis at appropriate places. The legal rules are not ignored in the narrative brief; indeed they are one of the essential strands. The client's story is the other essential strand.

I am not claiming that a narrative structure is inherently better than the IRAC paradigm for large-scale organization. Indeed,

\footnotetext{
${ }^{61}$ Burns, supra n. 33, at 1171.
} 
there may be cases in which a more formal, legalistic structure is better, or even necessary. For example, criminal defense lawyers, who frequently have unappealing clients, often choose to present technical legal defenses based upon procedural rules. ${ }^{62}$ Indeed, in any case where the facts strongly favor one side, the opposing side may be best advised to redirect the court's attention to the legal rules. ${ }^{63}$ That could be the only option if the opposing side cannot come up with a compelling counter-story of its own.

I am claiming, however, that an appellate brief writer ought to at least consider the narrative elements of every case, before writing a single word. Consciously thinking about the elements of character, conflict, theme, and point of view can lead the writer to make well-informed strategic choices about how to persuade the reader. ${ }^{64}$ And thinking about the plot and its natural trajectory can, in some (perhaps many) cases, lead to a coherent and highly readable brief.

\section{CONCLUSION}

As Ellen expected, OYDSS's brief was very technical and legalistic. It argued for rational basis review, based predominantly on a lack of United States Supreme Court precedent requiring heightened scrutiny in cases such as this. It contained few references to Margaret and Johnnie, and none to the foster care system that would await Johnnie should the court rule in favor of OYDSS.

\footnotetext{
${ }^{62}$ But see Foley \& Robbins, supra n. 8, at 473. Foley and Robbins describe criminal defense cases as a "special case" because the writer often has an "unsavory" client; however, they point out that the author can often find a persuasive story to tell by making the client "a proxy for an 'ideal,' such as the Fourth or Fifth Amendment: a holding against the client is a holding against the Fourth Amendment." Id.

${ }^{63}$ For example, the Old York County Department of Social Services may have a tough time writing its brief in a narrative form in this mock case. Advocates for the county would need to tread very lightly; their best strategy would likely be to attempt to distract the court's attention from the harsh image of the social worker arriving at Rubin's home to snatch a crying child from his mother's arms. It might be an interesting exercise for an advanced appellate advocacy class to write Old York County's brief in this case.

64 Obviously, the mock case described in this Article was "loaded" so that the facts were heavily on one side. We did this in our moot court problem to create a sort of balance between the two sides. We also wanted to create as "pure" a legal question as possible for the competition, so we needed to exclude possible factual disputes that could have arisen had Margaret Rubin not been a good mother. The extreme facts of this case also made it a good vehicle for this Article, since the strength of the narrative makes it easy to observe and analyze. My point here is that, even in cases where the facts are not as compelling, understanding the narrative can help the writer produce a more persuasive brief.
} 
Ellen invited Margaret to attend the oral argument. She had briefly considered asking Margaret to bring Johnnie to the argument, so the judges could see the two of them together, but she quickly rejected that idea. Not only did it seem too manipulative, there was a risk of causing some emotional trauma to Johnnie. Ellen was not sure how much of the argument Johnnie would be able to follow, but if she succeeded in making Johnnie's plight real to the court, Johnnie would probably have understood enough of it to become alarmed. But at least Ellen wanted the court to see Margaret as a real person and not just some abstract appellant in a paper dispute.

Ellen thought the oral argument went well. Because she had structured her brief as a narrative, when the court questioned her she was always able to bring Margaret and Johnnie into her answer. After all, she was asking the court to write the conclusion to the story; the judges needed to fully understand the story up to this point in order to write a satisfying conclusion. She felt the judges were engaged with the case and troubled by its implications.

The attorney for OYDSS stuck primarily to the law and, for the most part, was rewarded with technical questions regarding the appropriate level of scrutiny. But the court had been clearly troubled by the harsh result that OYDSS seemed to be asking for. Several judges asked questions about the foster care system and the possible impact of the statutory prohibition on Johnnie. Each time, his response returned to his own theme: that the legislative process reflected the will of the people and needed to be respected. It was not the place of the court to substitute its judgment for that of the democratically-elected legislators, he argued.

Ellen's rebuttal was short and to the point:

Counsel for the Department has just suggested that the democratic process is more important than the family bonds that Johnnie and Margaret Rubin have built. But any suggestion that legislators get to vote on whether Margaret Rubin is a good and loving mother stands centuries of child custody law on its head. That is irrational. This court must declare the Old York adoption statute unconstitutional.

As the judges filed out of the courtroom at the conclusion of the argument, Ellen sank down in her chair. Had she done enough? 
Margaret Rubin was quickly beside her. She took Ellen's hands in her own, and, in a tremulous voice, she said simply, "Thank you. For everything." 